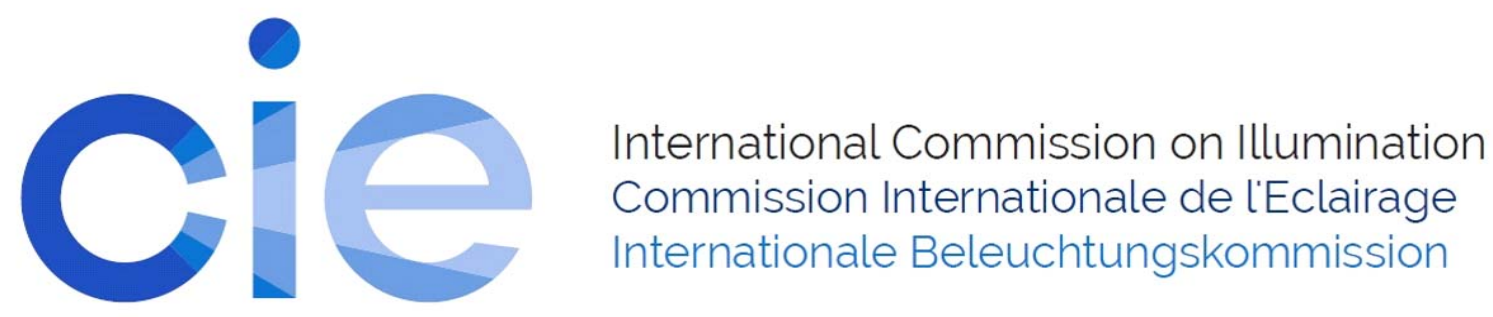

P0122

\title{
EFFECTS OF LIGHTING ON VISUAL IMPRESSIONS OF A MEETING ROOM IN VIRTUAL REALITY \\ Ya-Han Chung et al.
}

DOI 10.25039/x46.2019.PO122

from

CIE x046:2019

Proceedings

of the

29th CIE SESSION

Washington D.C., USA, June 14 - 22, 2019

(DOI 10.25039/x46.2019)

The paper has been presented at the 29th CIE Session, Washington D.C., USA, June 14-22, 2019. It has not been peer-reviewed by CIE.

(C) CIE 2019

All rights reserved. Unless otherwise specified, no part of this publication may be reproduced or utilized in any form or by any means, electronic or mechanical, including photocopying and microfilm, without permission in writing from CIE Central Bureau at the address below. Any mention of organizations or products does not imply endorsement by the CIE.

This paper is made available open access for individual use. However, in all other cases all rights are reserved unless explicit permission is sought from and given by the CIE.

CIE Central Bureau

Babenbergerstrasse 9

A-1010 Vienna

Austria

Tel.: +4317143187

e-mail: ciecb@cie.co.at

www.cie.co.at 


\title{
EFFECTS OF LIGHTING ON VISUAL IMPRESSIONS OF A MEETING ROOM IN VIRTUAL REALITY
}

\author{
Chung, Y., Ou, L. \\ National Taiwan University of Science and Technology, Taipei, CHINESE TAIPEI \\ chungyahan0310@gmail.com
}

DOI 10.25039/x46.2019.PO122

\begin{abstract}
The present study took a meeting room as an example to investigate how direct lighting and indirect lighting can affect visual impressions of a VR space. This study adopted 10 lighting designs for the room, and each design was assessed via 7 semantic scales. Experimental data show good repeatability for all but the relaxing/nervous scale, with correlation coefficients for each scale between visual responses given for the first time and those for the second time. The results indicate that direct lighting has a greater impact than indirect lighting on some visual impressions of the room.
\end{abstract}

Keywords: Interior Lighting, Virtual Reality, Visual Response

\section{Introduction}

Currently, the combination of direct and indirect lighting is commonly applied in the interior design, not only the lighting efficiency but also the visual experience. With increasing popularity of virtual reality (VR) technology, there is a strong demand for how this technology can be applied to interior design area as a communication tool between designer and customer.

Lighting as an environmental and architectural element can influence the viewer's perception, emotion and even behaviour. Little is known, however, of the impact of lighting on a VR space, in particular the difference between direct lighting and indirect lighting in their contribution to visual impressions of a VR space. As an initial attempt in this new area, the present study took meeting room as an example to investigate how lighting can affect visual impressions of a VR space.

\section{Methods}

To achieve this aim, a psychophysical experiment was conducted using a Miniso Simple 3D VR Glasses headset. A Huawei P20 smartphone, with a 5.8-inch screen and a resolution of $2240 \times 1080$ pixels, was used to present the VR images.

The 3DS MAX software was used to create a meeting room, $5.70 \mathrm{~m}$ (width) by $3.70 \mathrm{~m}$ (depth) by $2.85 \mathrm{~m}$ (height) in size, where a meeting table, with $3.55 \mathrm{~m}$ (width) by $1.40 \mathrm{~m}$ (depth) by $0.75 \mathrm{~m}$ (height) in size, was placed at the middle of the room, as shown in Figure 1

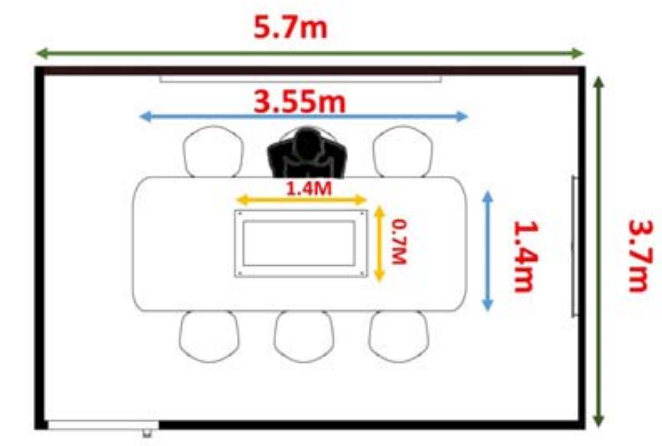

Figure 1 - The layout of the VR space used in the study 
This study adopted 10 lighting designs for the room, as summarised in Table 1.

Table 1 - The 10 lighting designs used in the study

\begin{tabular}{|c|c|c|c|}
\hline Design name & $\begin{array}{l}\text { Luminance measured } \\
\text { on the wall }\end{array}$ & $\begin{array}{c}\text { Luminance measured } \\
\text { on the table }\end{array}$ & scenes \\
\hline $\mathrm{AH}$ & $6.97 \mathrm{~cd} / \mathrm{m}^{2}$ & $33.83 \mathrm{~cd} / \mathrm{m}^{2}$ & \\
\hline AL & $2.03 \mathrm{~cd} / \mathrm{m}^{2}$ & $8.75 \mathrm{~cd} / \mathrm{m}^{2}$ & \\
\hline $\mathrm{BH}$ & $8.47 \mathrm{~cd} / \mathrm{m}^{2}$ & $34.01 \mathrm{~cd} / \mathrm{m}^{2}$ & \\
\hline$B L$ & $3.22 \mathrm{~cd} / \mathrm{m}^{2}$ & $8.80 \mathrm{~cd} / \mathrm{m}^{2}$ & \\
\hline $\mathrm{CH} 1$ & $14.48 \mathrm{~cd} / \mathrm{m} 2$ & $34.74 \mathrm{~cd} / \mathrm{m} 2$ & \\
\hline CL1 & $8.29 \mathrm{~cd} / \mathrm{m}^{2}$ & $9.49 \mathrm{~cd} / \mathrm{m}^{2}$ & \\
\hline $\mathrm{CH} 2$ & $6.44 \mathrm{~cd} / \mathrm{m}^{2}$ & $33.07 \mathrm{~cd} / \mathrm{m}^{2}$ & \\
\hline CL2 & $1.71 \mathrm{~cd} / \mathrm{m}^{2}$ & $8.25 \mathrm{~cd} / \mathrm{m}^{2}$ & \\
\hline $\mathrm{DH}$ & $7.49 \mathrm{~cd} / \mathrm{m}^{2}$ & $32.79 \mathrm{~cd} / \mathrm{m}^{2}$ & \\
\hline $\mathrm{DL}$ & $2.27 \mathrm{~cd} / \mathrm{m}^{2}$ & $7.90 \mathrm{~cd} / \mathrm{m}^{2}$ & \\
\hline
\end{tabular}

$\mathrm{AH}$ design - high intensity of direct lighting was created by a $1.40 \mathrm{~m}$ by $0.70 \mathrm{~m}$ pendant hollow LED panel; indirect lighting was provided by light cast upward to the central area of ceiling from LED strips hidden on a false ceiling installed around the ceiling lines. The measured luminance values from the VR image were $6.97 \mathrm{~cd} / \mathrm{m}^{2}$ for the main wall and $33.83 \mathrm{~cd} / \mathrm{m}^{2}$ for the table.

AL design - same as AH except the pendant LED panel provided low, instead of high, intensity of direct lighting. The measured luminance values were $2.03 \mathrm{~cd} / \mathrm{m}^{2}$ for the main wall and $8.75 \mathrm{~cd} / \mathrm{m}^{2}$ for the table. 
$\mathrm{BH}$ design - same as $\mathrm{AH}$ except there was additional indirect lighting created by light cast upward to the ceiling at the ceiling line areas from another set of LED strips installed near the ceiling lines. The luminance values were $8.47 \mathrm{~cd} / \mathrm{m}^{2}$ for the main wall and $34.01 \mathrm{~cd} / \mathrm{m}^{2}$ for the table.

$\mathrm{BL}$ design - same as $\mathrm{BH}$ except the pendant LED panel provided low intensity of direct lighting. The luminance values were $3.22 \mathrm{~cd} / \mathrm{m}^{2}$ for the main wall and $8.80 \mathrm{~cd} / \mathrm{m}^{2}$ for the table.

$\mathrm{CH} 1$ design - same as $\mathrm{BH}$ except the indirect lighting was created by light cast downward, instead of upward, from the LED strips. The luminance values were $14.48 \mathrm{~cd} / \mathrm{m}^{2}$ for the main wall and $34.74 \mathrm{~cd} / \mathrm{m}^{2}$ for the table.

CL1 design - same as $\mathrm{CH} 1$ except the pendant LED panel provided low intensity of direct lighting. The luminance values were $8.29 \mathrm{~cd} / \mathrm{m}^{2}$ for the main wall and $9.49 \mathrm{~cd} / \mathrm{m}^{2}$ for the table.

$\mathrm{CH} 2$ design - same as $\mathrm{CH} 1$ except the indirect lighting created by the LED strips was less bright for $\mathrm{CH} 2$ than for $\mathrm{CH} 1$. The luminance values were $6.44 \mathrm{~cd} / \mathrm{m}^{2}$ for the main wall and $33.07 \mathrm{~cd} / \mathrm{m}^{2}$ for the table.

CL2 design - same as $\mathrm{CH} 2$ except the pendant LED panel provided low intensity of direct lighting. The luminance values were $1.71 \mathrm{~cd} / \mathrm{m}^{2}$ for the main wall and $8.25 \mathrm{~cd} / \mathrm{m}^{2}$ for the table.

$\mathrm{DH}$ design - same as AH except the indirect lighting was created by LED strips that cast light upward to the ceiling at the ceiling line areas, instead of the central area. The luminance values were $7.49 \mathrm{~cd} / \mathrm{m}^{2}$ for the main wall and $32.79 \mathrm{~cd} / \mathrm{m}^{2}$ for the table.

DL design - same as DH except the pendant LED panel provided low intensity of direct lighting. The luminance values were $2.27 \mathrm{~cd} / \mathrm{m}^{2}$ for the main wall and $7.90 \mathrm{~cd} / \mathrm{m}^{2}$ for the table

These 10 designs were selected for this study to cover the most commonly used lighting solutions for a meeting room nowadays, as show in Figure 2. During the experiment, each of the designs were evaluated in VR using 7 semantic scales, like/dislike, relaxing/nervous, exciting/dull, intense/soft, spacious/tiny, safe/unsafe and bright/dark. For each observer, the 10 designs were presented in random order and were all presented twice. The observer responses were recorded and analysed using the categorical judgement scaling method.

A panel of 30 observers, including 15 males and 15 females, all university students with normal colour vision, participated in the study.

\section{Results}

Experimental data show good repeatability for all but the relaxing/nervous scale, with correlation coefficients for each scale between visual responses given for the first time and those for the second time, all greater than 0.85. Bright/dark shows the highest correlation coefficient $(R=0.98)$, whereas relaxing/nervous shows the lowest $(R=0.06)$. It is thus reasonable to remove visual data of relaxing/ nervous from further analysis due to its poor repeatability.

To compare the impacts of direct lighting and indirect lighting on the observer responses, the visual data were tested using ANOVA. The test results show that visual responses for the 6 scales are all significantly affected by direct lighting, with $p$ values all below 0.001 , whereas indirect lighting shows significant impact only on bright/dark $(p<0.001)$, exciting/dull $(p=0.002)$ and like/dislike $(p=0.031)$, as shown in Table 3 . The results suggest that direct lighting had a greater influence than indirect lighting on some visual impressions of the room.

The visual responses were also compared with luminance values measured on the main wall and on the meeting table. As a result, high correlation was found between luminance on the table and responses for each scale, with a mean correlation coefficient of 0.83 . High correlation was also found between luminance on the wall and the responses, with a mean correlation coefficient of 0.76 . 
Table 3 - ANOVA results for testing whether direct lighting and indirect lighting had a significant impact on the 7 scales studied

\begin{tabular}{ll|r|r|r|r|r|r}
\hline Source & $\begin{array}{l}\text { Dependent } \\
\text { Variable }\end{array}$ & $\begin{array}{c}\text { Type III Sum of } \\
\text { Squares }\end{array}$ & df & Mean Square & F & \multicolumn{1}{c|}{$\begin{array}{c}\text { Partial Eta } \\
\text { Squared }\end{array}$} \\
\hline indirect & like & 15.506 & 4 & 3.876 & 2.680 & .031 & .018 \\
& relaxing & 2.407 & 4 & .602 & .420 & .794 & .003 \\
& exciting & 21.437 & 4 & 5.359 & 4.345 & .002 & .029 \\
& soft & 1.672 & 4 & .418 & .296 & .880 & .002 \\
& spacious & 7.976 & 4 & 1.994 & 1.331 & .257 & .009 \\
& safe & 11.249 & 4 & 2.812 & 1.790 & .129 & .012 \\
& bright & 61.192 & 4 & 15.298 & 13.401 & .000 & .000 \\
\hline direct & like & 59.867 & 1 & 59.867 & 41.388 & .000 \\
& relaxing & .446 & 1 & .446 & .311 & .577 & .067 \\
& exciting & 162.104 & 1 & 162.104 & 131.421 & .000 & .001 \\
& soft & 43.590 & 1 & 43.590 & 30.905 & .000 & .185 \\
& spacious & 100.574 & 1 & 100.574 & 67.130 & .000 & .051 \\
& safe & 76.736 & 1 & 76.736 & 48.837 & .000 & .104 \\
& bright & 507.980 & 1 & 507.980 & 444.981 & .000 \\
\hline
\end{tabular}

\section{Conclusion}

A psychophysical experiment was conducted in a VR space, taking the meeting room as an example, to investigate the relationship between lighting design and visual impression of the room. The experimental results indicate that direct lighting has a greater impact than indirect lighting on some visual impressions of the room, and that the luminance measured on the meeting table has high correlation with the visual impressions. 